\title{
Factors associated with female sterilization in Brazil
}

\author{
Ernesto F. L. Amaral \\ Texas A\&M University \\ amaral@tamu.edu \\ Joseph E. Potter \\ The University of Texas at Austin \\ joe@prc.utexas.edu
}

\begin{abstract}
This study aims to investigate factors associated with female sterilization in Brazil. The analysis is innovative because it adds the time of exposure to the risk of sterilization into survival models. The models control for postpartum duration, age at delivery, parity at delivery, type of delivery, place of delivery, region of residence at the time of interview, color/race, and years of schooling at the time of interview. The main contribution of this analysis is to comprehend the effects of different birth intervals (postpartum duration) on the risk of a woman getting sterilized. Data is from the 2006 Brazilian National Survey on Demography and Health of Children and Women (PNDS). The strongest probability that sterilization might occur was observed among women who gave birth at private hospitals and received support from health insurance companies at childbirth. Female sterilization is also executed in combination with childbirth and cesarean section. The findings suggest that years of schooling do not predict the risk of sterilization. The higher chances of getting sterilized among black women are specific to the public sector at higher-order postpartum duration (interval sterilization).
\end{abstract}

\section{Keywords}

Contraceptive Agents. Female. Sterilization. Reproductive Health. Brazil.

\section{Acknowledgments}

We gratefully acknowledge Kari White for her support to set up the databases and estimate the regression models.

\section{Final publication}

Amaral EFL, Potter JE. (Forthcoming). "Factors associated with female sterilization in Brazil.” In: Developments in Demography in the 21st Century. (DL Poston Jr., J Singelmann, eds.). New York: Springer.

(http://doi.org/10.17605/OSF.IO/BD4RA) 


\title{
Factors associated with female sterilization in Brazil
}

\author{
Ernesto F. L. Amaral \\ and

\section{Joseph E. Potter}

\section{INTRODUCTION}

In this chapter we analyze factors associated with female sterilization in Brazil. We go beyond earlier analyses by adding a variable to the survival models that captures the amount of time of exposure to the risk of sterilization. We use data from the 2006 Brazilian National Survey on Demography and Health of Children and Women (PNDS). Our results are of special significance because, among other things, they aid our understanding of Brazil's remarkable decline in fertility from a total fertility rate of 6.3 children per woman in 1960 to 1.9 children per woman in 2010 , a fertility rate below the replacement level (IBGE, 2012). The increased use of modern contraception is a major factor associated with the fertility decline (Amorim, Cavenaghi, \& Alves, 2008; Berquó, Garcia, \& Lago, 2008; Cavenaghi \& Alves, 2009; Leone \& Hinde, 2005; Perpétuo, 1998; Perpétuo \& Wajnman, 2003; Perpétuo \& Wong, 2009). Of special interest is the fact that the two main contraceptive methods in Brazil are female sterilization and oral contraception (Janowitz et al., 1985; Perpétuo \& Wong, 2009; Potter, 1999; Vieira, 2007).

The increases in contraception in Brazil occurred in a context not associated with public policies on birth control (Fonseca Sobrinho, 1993). Brazil has most inadequate public services for sexual and reproductive health; they are characterized by excessive "medicalization"; the predominance of the private sector; delayed access to, and inappropriate use of, contraceptives; a lack of medical care; little availability of reversible methods; a high proportion of unwanted pregnancies; and social inequality regarding access to contraception (Bilac \& Rocha, 1998; Giffin 
\& Costa, 1999; Miranda-Ribeiro \& Simão, 2009; Schor et al., 2000; Vieira, 2007; Vieira \& Souza, 2009).

Analyses of female sterilization in Brazil are particularly important and timely for several reasons: (1) about 26 percent of married or cohabiting women between the ages 15 and 44 were sterilized in 2006; (2) there are legal requirements related to the access of female sterilization; (3) sterilization is for the most part an irreversible contraceptive method; (4) the availability of sterilization is associated with type and place of birth; (5) often there is evidence of regret among women after sterilization has been performed; (6) there is an indication of a frustrated demand for sterilization; (7) the public services for sexual and reproductive health are inadequate in the country; and (8) there is a need to expand the knowledge about female sterilization in Brazil.

Between 2000 and 2010, the main public health and medical journals available in the Scientific Electronic Library Online (SciELO) only published 31 papers about female sterilization in Brazil, out of a total of more than 6,000 publications (Minella, 2012).

The federal government implemented the family planning law in Brazil in 1997 (Brasil, 1996). One of the goals of this law was to make sterilization available in public hospitals, but with restrictions for surgeries during cesarean deliveries, childbirths, and abortions. Law No. 9263 from 1996 stated that "The surgical sterilization of a woman is forbidden during childbirth or abortion, except for health reasons caused by previous successive cesarean deliveries" (Law No. 9,263, Article No. 10, Paragraph No. 2 from January 12, 1996. Article 10 was vetoed until August 19, 1997. Document available on: http://www.camara.gov.br/sileg/integras/490199.pdf) (Brasil, 1996). Despite these legal impediments, female sterilization still occurs in conjunction with childbirths and cesarean sections (Barbosa \& Knauth, 2003; Berquó, 1999; Berquó \& Cavenaghi, 2003; Berquó et al., 2008; Carvalho, Osis, Cecatti, Bento, \& Manfrinati, 2007; Molina, 1999; Perpétuo \& Wong, 2009). Furthermore, the law states that female and male sterilizations are permitted only for persons above the age of 25 years, or for persons with at least two children born alive. Sterilizations may be performed no less than 60 days after the request, so there is time for counseling by a public 
multidisciplinary health group. Municipalities have insufficient public infrastructures and human resources to perform female sterilizations, and the regulations of the 1997 law appear to restrain the provision of this surgical procedure (Osis, Carvalho, Cecatti, Bento, \& Pádua, 2009).

Empirical evidence has shown that female sterilization has been more prevalent among women at older cohorts, with higher parity, with fewer years of education, with less educated spouses or companions, and among black and indigenous peoples (Amorim et al., 2008). Women with higher levels of education tended to be sterilized after they reached their ideal number of children as a result of planning for a specific number of offspring through the use of temporary contraceptives. By contrast, less educated women tended to be sterilized without having used another contraceptive method and usually after reaching more than the ideal number of children while experiencing shorter birth intervals (Perpétuo \& Wong, 2009). The option for sterilization seemed to be a result of higher fertility among women who started childbearing early in life (Osis, Faúndes, Sousa, Duarte, \& Bailey, 2003). We turn now to a review of the literature dealing with female sterilization.

\section{LITERATURE REVIEW}

Previous analyses have investigated numerous factors associated with the risk of female sterilization. For instance, marital status (married, cohabiting/in union, not in union) has been shown to be an important factor associated with female sterilization because some women tend to spend a great proportion of their lives outside of marriage or in less stable unions (Godecker, Thomson, \& Bumpass, 2001). Several studies have shown evidence of some regret of a female sterilization (Cunha, Wanderley, \& Garrafa, 2007; Curtis, Mohllajee, \& Peterson, 2006; Fernandes, Arruda, Palhares, Benetti Júnior, \& Moreira, 2001; Hopkins, 2009; Ludermir, Machado, Costa, Alves, \& Araújo, 2009; Machado, Ludermir, \& Costa, 2005; Perpétuo \& Wong, 2009; Vieira, 2007; Vieira et al., 2005). There is also evidence of a frustrated demand for female sterilization (Caetano, 
2014; Caetano \& Potter, 2004; Costa, Paes, Ramos, \& Formiga, 2006; Lacerda, Miranda-Ribeiro, Caetano, \& Machado, 2005; Osis et al., 2009; Potter et al., 2003).

Further, analyses of the differentials in the risk of sterilization have examined the types of delivery (vaginal birth or cesarean section). A large percentage of unnecessary cesarean deliveries have occurred as a way for women to obtain access to sterilization. Since sterilization is more difficult to obtain in the public sector, women might have entered the private sector in order to obtain this procedure, in conjunction with a cesarean delivery (Barbosa \& Knauth, 2003; Caetano \& Potter, 2004; Carvalho et al., 2007; Costa et al., 2006; Lacerda et al., 2005; Osis et al., 2009; Potter et al., 2003). There is an extreme inequality regarding access to female sterilization between the public and private sectors (Costa et al., 2006).

The causal relations that exist between cesarean section, female sterilization, and types of hospital are complex. Women who wish to become sterilized might choose a cesarean section at a private hospital where they have easier access to this type of service. Because of this endogeneity issue, we will estimate models later in this chapter that are separated by type of delivery. Furthermore, private hospitals might not directly increase the probability of female sterilization, yet the demand of the contraceptive method has been shown to result in an increase at private hospitals in the selection of cesareans. Thus, we will treat our results as factors associated with female sterilization, instead of as determinants of female sterilization.

Studies about factors associated with female sterilization in Brazil have not considered the effects of different birth intervals (postpartum duration) on the risk of a woman becoming sterilized. Analyses conducted in the United States have estimated models predicting the chances of women having a postpartum or interval sterilization according to race/ethnicity and insurance status (White \& Potter, 2014). The results have shown that low-income African Americans and Latinas are less likely to undergo female sterilization following childbirth, compared to low-income whites. This might be an indication of the fact that low-income may well minorities experience bureaucratic barriers when seeking to obtain an interval sterilization. We will introduce similar considerations in 
our Brazilian models, in order to overcome the limitations of preceding analyses. We will add into our survival models the time of exposure to the risk of sterilization. Based on analyses of sterilization in the U.S., our main hypothesis will be that the significant effects of color/race and years of schooling are a result of higher exposed risks to undergo a sterilization procedure among women with higher fertility rates (black and lower educated). When person months of exposure is taken into account, the effects of color/race and years of schooling are expected to lose their significance.

In summary, we will investigate factors associated with female sterilization in Brazil between January 2001 and July 2007. The innovative contribution of this analysis will be the analysis of the effects of different birth intervals on the risk of female sterilization. Our research study is not limited to a cross-sectional investigation. The data are organized by postpartum duration, in order to estimate the risks of sterilization at childbirth (zero months), as well as the risks of interval sterilization (that is, intervals of 1, 2, 3-6, 7-12, 13-18, and 19+ months). In order to conduct this exercise, our models will be controlled for a series of characteristics of women.

In the next section of this chapter, we discuss our data and methods. In later sections we present the main results of our analyses, and discuss our main findings.

\section{DATA AND METHODS}

The data we use in the analyses we undertake in this chapter are drawn from the 2006 Brazilian National Survey on Demography and the Health of Women and Children (PNDS). The subjects of our analyses are women between the ages of 15-49 at the time of the interview, who had experienced a live birth between January 2001 and the date of the interview. The data are from four separate questionnaires gathering information on households/individuals $(n=56,365)$, women $(n=15,575)$, pregnancy histories $(n=6,833)$, and childbirth histories $(n=27,477)$. By aggregating the variables from the different databases, our data will refer to pregnancies occurring between January 2001 and July 2007, the specific period that covered the histories of pregnancies and childbirth. 
Although we will use data from the 2006 PNDS, pregnancies are reported in the database up to July 2007.

We estimate proportional hazard $(\mathrm{PH})$ models predicting the risk of women becoming sterilized (Blossfeld, Golsch, \& Rohwer, 2007; Blossfeld \& Rohwer, 2002; Godecker et al., 2001; Leon \& Potter, 1989; Leone \& Hinde, 2005; Steele, 2003). Several parametric models, e.g., Gompertz models, Weibull models, exponential models, and other parametric models, make strong assumptions about the shape of the hazard function. We estimate Cox semi-parametric models in our analyses because they make no such assumptions. Specifically, piece-wise constant exponential models will be fitted to our data. The hazard is assumed to be constant within pre-specified survival time intervals. But, the constant may well differ for different intervals. The hazard function $\left[h\left(t_{i j}\right)\right]$ assesses the risk at a particular moment that an individual who has not yet done so will experience the target event. This specification can be generalized to have a constant hazard within each interval along the survival time axis. In order to accomplish this exercise, the data were reorganized to create several time-varying covariates. Variables were generated to allow the constant term in the hazard regression to differ from interval to interval. The baseline hazard may differ over seven postpartum duration intervals (in months) in which a woman was exposed to the risk of sterilization $(0,1,2,3-6,7-12,13-18,19+)$. A time indicator variable was created for each interval $J$, in the form of seven dummy variables $\left(D_{J}\right)$, to link the episodes in the reorganized data with these time intervals. A set of $P$ substantive predictors $\left(X_{P}\right)$ was generated, as individual characteristics, which yield a vector of regression coefficients $\left(\beta_{P}\right)$. The discrete-time hazard model can be written as follows:

$\operatorname{logit} h\left(t_{j}\right)=\left[\alpha_{0} D_{0}+\alpha_{1} D_{1}+\alpha_{2} D_{2}+\alpha_{3-6} D_{3-6}+\alpha_{7-12} D_{7-12}+\alpha_{13-18} D_{13-18}+\alpha_{19+} D_{19+}\right]+\left[\beta_{1} X_{1}+\ldots+\right.$ $\left.\beta_{P} X_{P}\right]$ 
The above equation eliminates the subscript $i$ for individuals, because its presence is implicit. Moreover, this representation excludes the subscript $j$ for time periods from the right side of the equation, because it is either redundant (for the time indicators) or implicit (for the substantive predictors) (Singer $\&$ Willett, 2003). Each intercept parameter, $\alpha_{0}, \alpha_{1}, \ldots, \alpha_{19+}$, represents the value of the logit hazard (the log odds of event occurrence) in that particular time period for individuals in the baseline groups. Each slope parameter, $\beta_{1}, \beta_{2}, \ldots, \beta_{P}$, assesses the effect of a one unit difference in that predictor on event occurrence, statistically controlling for the effects of all the other predictors in the model.

All seven duration intervals could be included as covariates if the constant term was excluded. However, we opted to include the constant term, use the one interval of zero months as the reference category. This option provides for us a direct interpretation of how the baseline hazards for the six remaining intervals differ from the reference interval. These two forms of estimation are similar and would generate the same predicted values.

The regression tables produced by estimating our models will report exponentiated coefficients $\left[\exp \left(\beta_{P}\right)\right]$, known as hazard ratios. Graphs will illustrate the cumulative predicted hazards (cumulative probabilities of becoming sterilized). The cumulative hazard function assesses, at each point in time, the total amount of accumulated risk that an individual has faced from the beginning of time until the present.

The steps we follow in estimating the models are the following:

1. Establish the complex survey design (strata and primary sampling unit) and the expansion factor of women (individual weight) using Stata's "svyset" command. The strata are the combined five major regions (North, Northeast, Southeast, Central-West, and South) and household situation (urban and rural). The primary sampling unit is formed by the census tracts (conglomerate).

2. Indicate that this study is based on a survival analysis, with starting and ending times of exposure to the risk of sterilization, as well as note the sterilization event, with Stata's "stset" command. This initial database utilizes pregnancies as the unit of analysis. 
3. Organize the database with postpartum duration (in months) as the unit of analysis by disaggregating pregnancies into the different times that a woman was at the risk of becoming sterilized. Every pregnancy was disaggregated into units of analysis that indicate the exposure of women to a specific postpartum duration. This procedure allows us to check the effects of the time of the exposure of women after delivery/childbirth (postpartum duration) to the event of sterilization. The time of delivery/childbirth (in months) is used to determine the postpartum duration that a woman was exposed to the risk of sterilization, namely, $0,1,2,3-6,7-12,13-18$, and 19+ months. The computer software compares the initial time of exposure to the risk of sterilization (postpartum period) with the final time of exposure (already calculated) to define how many times each pregnancy will be disaggregated in the database. Stata's "stsplit" command disaggregates the unit of analysis (pregnancy) into the different times that a woman entered the next postpartum period and was exposed to the risk of sterilization. The initial time of exposure is recalculated, considering the final time of the preceding postpartum period for each woman.

4. Indicate, once again, that this study is based on a survival analysis, but now with the ending time of the postpartum period ("stset" command).

5. Estimate piece-wise constant exponential regression models, in order to understand the effect of postpartum periods and other independent variables on the risk of female sterilization, with the "svy: streg, d(exp)" command. These models are estimated using the exponential distribution.

From the initial database with 6,833 pregnancies, there were a total of 5,890 pregnancies that resulted in live births between January 2001 and July 2007 with valid information for all the variables of interest. However, some cases were dropped from our study. The final database with 3,398 pregnancies was disaggregated into postpartum durations. Thus, the unit of analysis is postpartum duration $(0,1,2,3-6,7-12,13-18,19+$ months $)$ with a total sample size of 17,376 observations. In order to reach this final number, models include only one observation for cases of multiple births (51 births excluded). Women who did not remember their own date of birth (four women), date of sterilization (42 women), or date of delivery/childbirth (one woman) were also 
excluded. The estimates exclude women who gave birth in health centers (responsible for 94 postpartum records), since none of them were sterilized and would have been automatically dropped from the regression models. Women with deliveries at home were also removed from the analysis (related to 1,290 postpartum records), because, obviously, they were not at risk of becoming sterilized because the birth occurred at home without a medical doctor. Women with one child ever born at the time of delivery were not included in the models (corresponding to 13,808 postpartum records), because of their rather small likelihood of becoming sterilized.

Information on female sterilization was used as the dependent variable, considering the month and year of sterilization. The independent variables associated with the risk of female sterilization are listed on Table 1. Information on region of residence and years of schooling might change over time. However, the database does not provide data on possible changes, so our variables dealing with residence and schooling pertain to their measurement at the time of interview.

\section{>> Table 1 About Here $<<<$}

Previous models predicting the risk of sterilization have included information about marital status (married, cohabiting/in union, not in union) (Godecker et al., 2001) and number of unions experienced by women (Leone \& Hinde, 2005). Our preliminary analyses indicated that married women are more likely to become sterilized than cohabiting women. Also, we found that number of unions did not present statistically significant results. However, we did not include in our analyses information on marital status and number of marriages/unions because they might introduce problems of endogeneity into the regression models.

A total of 100 women reported male sterilization as their form of contraception. However, the date that the vasectomy occurred is not available in the database. Therefore, our models do not 
estimate the impact of vasectomy on the risk of female sterilization, despite its significance in previous analyses (Oliveira, 2003; Oliveira, Bilac, \& Muszkat, 2009).

We estimated a series of models predicting the risk of female sterilization. Some models took into account only cases concerning cesarean sections or vaginal births, in order to verify differentials in the risk of sterilization by type of delivery. This exercise considered the woman who wanted to become sterilized who gave birth in the private sector in order to have access to this procedure following a cesarean delivery (Barbosa \& Knauth, 2003; Caetano \& Potter, 2004; Carvalho et al., 2007; Costa et al., 2006; Lacerda et al., 2005; Osis et al., 2009; Potter et al., 2003).

Five models were estimated examining factors associated with female sterilization. The first three models differed in terms of inclusion of the samples. The first model included all observations in the sample; the second include a subset of the sample with observations related to cesarean section; and the third included a subset related to vaginal delivery observations. All three models included the main effects of all the independent variables noted above.

The other two models tested interactions among the main effects for all the observations in the sample and for cases related to cesarean section. The interaction models did not converge for the subset related to vaginal deliveries, mainly due to small sample size in some categories of postpartum duration (e.g., 0, 1, 2 months). Three sets of interactions were designed: (1) interactions between age at delivery and parity at delivery to account for older women with higher parity possibly witnessing higher risks of sterilization than younger women with lower parity; (2) interactions between place of delivery and postpartum duration to look into whether women in private hospitals have higher chances of getting sterilized during childbirth, comparing to those in public hospitals within zero months after delivery; and (3) interactions between place of delivery and parity at delivery to test whether women within public hospitals (SUS) might been having difficulties to get sterilized even with higher parity, comparing to those with lower parity. Complex survey design was applied to estimate the regression models. All analyses were performed with Stata, version 13.1. 


\section{RESULTS}

Our data include women who were exposed to the risk of sterilization for a total of 88,228 months, resulting in 855 women being sterilized between 2001 and 2007 (Table 2). As a result of the range of categories used for the postpartum duration $(0,1,2,3-6,7-12,13-18$, and 19+ months), the number of person months of exposure to the risk of female sterilization is the greatest in the $19+$ month category $(35,632)$. The number of events of sterilization is most concentrated at the moment of delivery (657 events). In relation to age at the time of delivery, women in the 30-34 year age group have a large number of events of sterilization (202), in comparison to their person months of exposure to the risk of sterilization $(13,245)$, resulting in a percentage of 1.53 . Women with two children at delivery have a longer exposure time and more events of sterilization, but a lower percentage (0.70). Women who delivered their babies at private hospitals present an increased incidence of sterilization (167 events) in relation to their person months of exposure (3,832 months), representing 4.36 percent. Women in the North present the most number of events of sterilization, in relation to their person months of exposure (1.28 percent). In terms of color/race, the majority of the sample is composed of births from brown (51.65 percent) and white ( 33.23 percent) women, with the highest number of sterilization events. Information on educational attainment indicates that women with at least 11 years of schooling have the highest number of sterilization events in relation to their person months of exposure (1.27 percent).

\section{>> Table 2 About Here $<<<$}

Table 3 illustrates the exponential function of the coefficients from three hazard models. The first model includes all observations in the sample and indicates that the risk of female sterilization is 94 percent lower $\left[(0.06-1)^{*} 100\right]$ in the month following a birth, compared to the risk of sterilization at the same time of delivery. And the risk of sterilization increases with age. For 
instance, women between 30-34 years of age are 3.3 times more likely to become sterilized than women between 15-24 years of age. In terms of parity at delivery, women with two children at the time of a birth present the highest risk of being sterilized among all parity groups. In relation to place of delivery, women giving birth at private hospitals have 3.9 higher chances to become sterilized, compared to women at public hospitals (SUS). The coefficients of region of residence suggest that women living in the North are 1.4 times more likely to become sterilized than those living in the Southeast. With regard to color/race, black women are 42 percent more likely to become sterilized compared to white women. The coefficients for years of schooling were not statistically significant.

\section{>> Table 3 About Here $<<<$}

Another model was estimated only for observations related to cesarean section delivery (Table 3). The hazard ratios for interval sterilization (1+ months) are lower than in the previous model. This is an indication that sterilization at childbirth has been performed in conjunction with cesarean sections. This pattern seems to be happening all over the country, since the region of residence coefficients lost their statistical significance in this model. It appears that for women with vaginal deliveries, sterilization at childbirth (zero months) happens in a lower level after birth compared to women with cesarean sections, which is probably due to medical recommendations. In terms of parity at delivery, women with two children at the time of a birth present the lowest risk of being sterilized among all parity groups, which is the opposite of our findings in the previous models. In relation to place of delivery, women giving birth with the support of health insurance are 79 percent less likely to become sterilized than women at public hospitals. The coefficients of region of residence suggest that women living in the North are 1.9 times more likely to become sterilized than women living in the Southeast. 
Figure 1 illustrates the cumulative predicted hazard of sterilization from the estimated models by postpartum duration and place of delivery for the 25-29 age group, parity of two children, living in the Brazilian Southeast. The predicted hazards show much higher chances of becoming sterilized for women who have a cesarean section, instead of a vaginal delivery. These chances are higher at childbirth, mostly for women having birth in private hospitals with cesarean section. The cumulative hazards do not increase considerably among women with cesarean section, indicating that most sterilization happens at childbirth and not in interval sterilization.

\section{>> Figure 1 About Here $<<<$}

Table 4 presents the results for the two models that control for interactions among the independent variables: (1) age at delivery * parity at delivery; (2) place of delivery * postpartum duration; and (3) place of delivery * parity at delivery. The statistical software dropped several categories, due to few observed cases, which tends to increase the standard errors and decrease the statistical significance. In general, region of residence, color/race, and years of schooling have similar results to the main effects model.

\section{>> Table 4 About Here $<<<$}

In the first model with all observations (Table 4), the interactions between age and parity indicate that, among women with two children at the time of delivery, those between 35-49 years of age have the highest risk of becoming sterilized (4.5 times more likely), compared to women between 15-24 years of age with two children at the time of delivery. Among women with four children or more, those between 35-49 years of age have 4.6 higher risks of becoming sterilized, compared to women in the reference category. Interactions between place of delivery and postpartum duration indicate higher risks of sterilization for women giving birth with the support of 
health insurance or at private hospitals at the moment of delivery, compared to women in public hospitals within the same postpartum duration. Women within zero months postpartum are 5.3 times more likely to become sterilized if they are in private hospitals, compared to women in the reference category.

Another set of variables evaluates the interaction between place and parity at the time of delivery. At public hospitals, women are less likely to become sterilized if they have four children or more (49 percent less likely), compared to women with two children.

The second model shown in Table 4 has the results for the interactions related to the observations of cesarean section. This model reports the same trends as in the model with all women. However, the hazard ratios for the cesarean section model tend to be smaller than in the previous model. For instance, women within zero months postpartum are 2.0 times more likely to become sterilized if they are in private hospitals, compared to women in the reference category, in this subset model, while in the overall model this ratio equals 5.3. This is an indication that the chances of sterilization are high among all women having a cesarean section, independent of their characteristics.

\section{DISCUSSION}

The analyses reported in this chapter estimated the risk of Brazilian women becoming sterilized, taking into account the time of sterilization with data on their birth history. Our analyses build on previously estimated models (Godecker et al., 2001; Leon \& Potter, 1989; Leone \& Hinde, 2005; Steele, 2003; White \& Potter, 2014). The estimations consider the time of exposure to the risk of female sterilization, as well as the effects of postpartum duration in a longitudinal analysis. Women have a higher risk of becoming sterilized following childbirth, despite the regulations of the 1997 family planning law in Brazil.

One could argue that women are being forced to become sterilized, which might cause regret among them following the procedure (Cunha et al., 2007; Curtis et al., 2006; Fernandes et al., 
2001; Hopkins, 2009; Ludermir et al., 2009; Machado et al., 2005; Perpétuo \& Wong, 2009; Vieira, 2007; Vieira et al., 2005). However, our models indicate that sterilization is greater among older women, those with two children at delivery, as well as in areas of elevated fertility rates (North and Northeast regions). Women who gave birth at private hospitals or with the support of health insurance were shown to experience the greatest chances of becoming sterilized following a birth. This is an indication that these women may not have been able to become sterilized at public hospitals. Even women with higher-order parity (4+ children) have lower chances of sterilization at public hospitals. Brazil's family planning law allows sterilization only for people above 25 years of age or with at least two children born alive. This might be a reason why women between 15 and 24 years of age, even with two children ever born, were shown to experience low risks of sterilization, compared to women in the other age groups.

The 1997 Brazilian family planning law established restrictions for female sterilization in public hospitals for surgeries during cesarean deliveries, childbirth, and abortion. However, a large percentage of sterilizations has been occurring using health insurance or at private hospitals. Female sterilization has also been shown to occur in combination with childbirth and cesarean section. Women might be going to the private sector in order to be sterilized, following an unnecessary cesarean delivery (Barbosa \& Knauth, 2003; Berquó, 1999; Berquó \& Cavenaghi, 2003; Berquó et al., 2008; Caetano \& Potter, 2004; Carvalho et al., 2007; Costa et al., 2006; Lacerda et al., 2005; Molina, 1999; Osis et al., 2009; Perpétuo \& Wong, 2009; Potter et al., 2003). The law could be altered in order to allow female sterilization in conjunction with childbirth (Potter et al., 2003) as a way to address the demand of women in public hospitals.

Previous studies have suggested that higher levels of female sterilization are associated with color/race (higher incidences among black and indigenous women) and with lower levels of educational attainment (Amorim et al., 2008; Perpétuo \& Wong, 2009). However, our findings suggest that color/race and years of schooling are not very good predictors of the risk of female sterilization, when the models take into account the months of exposure to the risk of sterilization. 
We only observed an effect for black women, who have higher chances of becoming sterilized than white women. The estimated cumulative predicted hazards of sterilization indicate that black women are not subject to the high risks of sterilization at private hospitals and with the support of health insurance. Black women usually have their births at public hospitals, which may well be due to financial restrictions. As a result, they have risks of sterilization at public hospitals at higherorder postpartum duration (interval sterilization), compared to white and brown women. This is some evidence that black women are not been able to become sterilized at public hospitals at childbirth, probably due to the regulations of the family planning law. White and brown women were shown to experience a higher proportion of births at private hospitals, as well as with the support of health insurance, which resulted in higher cumulative predicted hazards of sterilization among these women.

The high prevalence of sterilization in private institutions should be a concern for the government. Policies are necessary not only to regulate the public sector, but also to provide better and more inclusive services at private institutions. The government needs to implement family planning programs with appropriate health care, guidance, and access to sexual and reproductive health services for all women (Bilac \& Rocha, 1998; Carvalho et al., 2007; Costa et al., 2006; Giffin \& Costa, 1999; Miranda-Ribeiro \& Simão, 2009; Schor et al., 2000; Vieira et al., 2005; Vieira \& Souza, 2009). Access to more options related to modern contraceptive methods must be provided, as well as appropriate medical follow-ups, which would prevent women from facing the financial and emotional burdens by themselves. 
Table 1. Independent variables associated with the risk of female sterilization

\begin{tabular}{ll}
\hline Independent variables & Categories \\
\hline 1. Postpartum duration in & 0 \\
months & 1 \\
& 2 \\
& $3-6$ \\
& $7-12$ \\
& $13-18$ \\
& $19+$ \\
\hline 2. Woman's age in years at & $15-24$ \\
time of delivery & $25-29$ \\
& $30-34$ \\
& $35-49$ \\
\hline 3. Parity at delivery, & 2 children \\
calculated with & 3 children \\
information about & 4 children or more \\
number of children ever & \\
born and birth order & \\
\hline 4. Place of delivery & Public hospital (SUS) \\
& Health insurance ("convênio") \\
& Private hospital \\
\hline 5. Region of residence at & North \\
the time of interview & Northeast \\
& Southeast \\
& Central-West \\
South \\
\hline 6. Color/race & White ("branca") \\
& Black ("preta") \\
& Brown ("parda") \\
time of interview & Yellow/Asian ("amarela") \\
& Indigenous ("indigenous") \\
\hline 7. Years of schooling at the & 0-3 (less than first phase of elementary school) \\
& 8-10 (from completed first phase of elementary school to less than second phase of \\
& scompleted second phase of elementary school to less than secondary \\
& $11+$ (from completed secondary school and above) \\
\hline
\end{tabular}

Source: 2006 Brazilian National Survey on Demography and Health of Children and Women (PNDS). 
Table 2. Distribution of births, person months of exposure, and female sterilizations among women delivering live born infants within five years of the survey date, Brazil, January 2001 to July 2007

\begin{tabular}{|c|c|c|c|c|c|}
\hline Variables & Births & $\begin{array}{c}\text { Births } \\
(\%)\end{array}$ & $\begin{array}{l}\text { Person months } \\
\text { of exposures }\end{array}$ & $\begin{array}{c}\text { Female } \\
\text { sterilizations }\end{array}$ & $\begin{array}{l}\text { Sterilizations / } \\
\text { Exposures (\%) }\end{array}$ \\
\hline Sample size (n) & 3,398 & 100,00 & 88,228 & 855 & 0.97 \\
\hline \multicolumn{6}{|l|}{ Postpartum duration (months) } \\
\hline 0 & - & - & 12,975 & 657 & 5.06 \\
\hline 1 & - & - & 2,731 & 25 & 0.92 \\
\hline 2 & - & - & 2,667 & 17 & 0.64 \\
\hline $3-6$ & - & - & 10,001 & 56 & 0.56 \\
\hline $7-12$ & - & - & 13,195 & 26 & 0.20 \\
\hline $13-18$ & - & - & 11,027 & 24 & 0.22 \\
\hline $19+$ & - & - & 35,632 & 50 & 0.14 \\
\hline \multicolumn{6}{|l|}{ Age at delivery (years) } \\
\hline $15-24$ & 1,420 & 41.79 & 40,331 & 230 & 0.57 \\
\hline $25-29$ & 974 & 28.66 & 24,991 & 280 & 1.12 \\
\hline $30-34$ & 586 & 17.25 & 13,245 & 202 & 1.53 \\
\hline $35-49$ & 418 & 12.30 & 9,661 & 143 & 1.48 \\
\hline \multicolumn{6}{|l|}{ Parity at delivery } \\
\hline 2 children & 1,682 & 49.50 & 46,586 & 327 & 0.70 \\
\hline 3 children & 889 & 26.16 & 21,863 & 288 & 1.32 \\
\hline 4 children or more & 827 & 24.34 & 19,779 & 240 & 1.21 \\
\hline \multicolumn{6}{|l|}{ Place of delivery } \\
\hline Public hospital (SUS) & 2,845 & 83.73 & 77,226 & 593 & 0.77 \\
\hline Health insurance ("convênio") & 287 & 8.45 & 7,170 & 95 & 1.32 \\
\hline Private hospital & 266 & 7.83 & 3,832 & 167 & 4.36 \\
\hline \multicolumn{6}{|c|}{ Region of residence at the time of interview } \\
\hline North & 735 & 21.63 & 16,818 & 216 & 1.28 \\
\hline Northeast & 639 & 18.81 & 16,402 & 158 & 0.96 \\
\hline Southeast & 646 & 19.01 & 17,833 & 154 & 0.86 \\
\hline Central-West & 677 & 19.92 & 20,273 & 123 & 0.61 \\
\hline South & 701 & 20.63 & 16,902 & 204 & 1.21 \\
\hline \multicolumn{6}{|l|}{ Color/Race } \\
\hline White ("branca") & 1,129 & 33.23 & 31,377 & 266 & 0.85 \\
\hline Black ("preta") & 340 & 10.01 & 8,873 & 76 & 0.86 \\
\hline Brown ("parda") & 1,755 & 51.65 & 43,123 & 473 & 1.10 \\
\hline Yellow/Asian ("amarela") & 91 & 2.68 & 2,754 & 23 & 0.84 \\
\hline Indigenous ("indígena") & 83 & 2.44 & 2,101 & 17 & 0.81 \\
\hline \multicolumn{6}{|c|}{ Years of schooling at the time of interview } \\
\hline $0-3$ & 692 & 20.36 & 17,325 & 168 & 0.97 \\
\hline $4-7$ & 1,320 & 38.85 & 35,470 & 301 & 0.85 \\
\hline $8-10$ & 699 & 20.57 & 18,668 & 173 & 0.93 \\
\hline $11+$ & 687 & 20.22 & 16,765 & 213 & 1.27 \\
\hline
\end{tabular}

Note: This table was constructed without taking into account the complex survey design.

Source: 2006 Brazilian National Survey on Demography and Health of Children and Women (PNDS). 
Table 3. Exponentiated coefficients from hazard models (hazard ratios) estimating the risk of sterilization (main models), Brazil, January 2001 to July 2007

\begin{tabular}{|c|c|c|c|}
\hline Variables & $\begin{array}{c}\text { All } \\
\text { women }\end{array}$ & $\begin{array}{l}\text { Cesarean } \\
\text { Section }\end{array}$ & $\begin{array}{l}\text { Vaginal } \\
\text { delivery }\end{array}$ \\
\hline $\begin{array}{l}\text { Postpartum duration (months) } \\
0\end{array}$ & ref. & ref. & ref. \\
\hline 1 & $\begin{array}{c}0.06 * * * \\
(0.02)\end{array}$ & $\begin{array}{c}1.51 \mathrm{e}-17 * * * \\
(1.24 \mathrm{e}-18)\end{array}$ & $\begin{array}{c}0.63 \\
(0.21)\end{array}$ \\
\hline 2 & $\begin{array}{c}0.06^{* * *} \\
(0.02)\end{array}$ & $\begin{array}{l}0.01 * * * \\
(0.00)\end{array}$ & $\begin{array}{c}0.61 \\
(0.22)\end{array}$ \\
\hline $3-6$ & $\begin{array}{c}0.06^{* * * *} \\
(0.01)\end{array}$ & $\begin{array}{c}0.01 * * * \\
(0.01)\end{array}$ & $\begin{array}{c}0.55^{* *} \\
(0.15)\end{array}$ \\
\hline $7-12$ & $\begin{array}{c}0.02 * * * \\
(0.01)\end{array}$ & $\begin{array}{c}0.01 * * * \\
(0.00)\end{array}$ & $\begin{array}{c}0.20 * * * \\
(0.08)\end{array}$ \\
\hline $13-18$ & $\begin{array}{l}0.02 * * * \\
(0.01)\end{array}$ & $\begin{array}{l}0.01 * * * \\
(0.00)\end{array}$ & $\begin{array}{l}0.11 * * * \\
(0.04)\end{array}$ \\
\hline $19+$ & $\begin{array}{c}0.01 * * * \\
(0.00)\end{array}$ & $\begin{array}{l}0.01 * * * \\
(0.00)\end{array}$ & $\begin{array}{c}0.13 * * * \\
(0.03)\end{array}$ \\
\hline $\begin{array}{l}\text { Age at delivery (years) } \\
15-24\end{array}$ & ref. & ref. & ref. \\
\hline $25-29$ & $\begin{array}{l}2.31 * * * \\
(0.38)\end{array}$ & $\begin{array}{c}2.36 * * * \\
(0.48)\end{array}$ & $\begin{array}{c}1.37 \\
(0.34)\end{array}$ \\
\hline $30-34$ & $\begin{array}{l}3.26 * * * \\
(0.67)\end{array}$ & $\begin{array}{l}3.12 * * * \\
(0.81)\end{array}$ & $\begin{array}{c}1.27 \\
(0.38)\end{array}$ \\
\hline $35-49$ & $\begin{array}{c}3.55^{* * *} \\
(0.70) \\
\end{array}$ & $\begin{array}{c}3.12 * * * \\
(0.80)\end{array}$ & $\begin{array}{c}1.03 \\
(0.38) \\
\end{array}$ \\
\hline $\begin{array}{l}\text { Parity at delivery } \\
2 \text { children }\end{array}$ & ref. & ref. & ref. \\
\hline 3 children & $\begin{array}{c}0.76^{*} \\
(0.11)\end{array}$ & $\begin{array}{c}0.60 * * * \\
(0.10)\end{array}$ & $\begin{array}{c}2.02 * * * \\
(0.51)\end{array}$ \\
\hline 4 children or more & $\begin{array}{l}0.58 * * * \\
(0.12)\end{array}$ & $\begin{array}{l}0.53 * * * \\
(0.11)\end{array}$ & $\begin{array}{l}1.98 * * \\
(0.56)\end{array}$ \\
\hline $\begin{array}{l}\text { Place of delivery } \\
\text { Public hospital (SUS) }\end{array}$ & ref. & ref. & ref. \\
\hline Health insurance (“convênio") & $\begin{array}{l}1.43 * \\
(0.29)\end{array}$ & $\begin{array}{c}0.89 \\
(0.18)\end{array}$ & $\begin{array}{l}0.21^{*} \\
(0.19)\end{array}$ \\
\hline Private hospital & $\begin{array}{l}3.92 * * * \\
(0.77)\end{array}$ & $\begin{array}{l}2.20 * * * \\
(0.35)\end{array}$ & $\begin{array}{c}1.82 \\
(0.98) \\
\end{array}$ \\
\hline $\begin{array}{l}\text { Region of residence at the time of interview } \\
\text { North }\end{array}$ & $\begin{array}{l}1.35^{*} \\
(0.22)\end{array}$ & $\begin{array}{c}1.08 \\
(0.20)\end{array}$ & $\begin{array}{l}1.89 * \\
(0.71)\end{array}$ \\
\hline $\begin{array}{l}\text { Northeast } \\
\text { Southeast }\end{array}$ & $\begin{array}{l}1.34^{*} \\
(0.21) \\
\text { ref. }\end{array}$ & $\begin{array}{l}1.25 \\
(0.22) \\
\text { ref. }\end{array}$ & $\begin{array}{l}1.71 \\
(0.57) \\
\text { ref. }\end{array}$ \\
\hline $\begin{array}{l}\text { South } \\
\text { Central-West }\end{array}$ & $\begin{array}{c}0.75 \\
(0.14) \\
1.24 \\
(0.19)\end{array}$ & $\begin{array}{c}0.75 \\
(0.14) \\
1.06 \\
(0.167) \\
\end{array}$ & $\begin{array}{c}0.53 \\
(0.22) \\
1.22 \\
(0.48)\end{array}$ \\
\hline $\begin{array}{l}\text { Color/Race } \\
\text { White ("branca") }\end{array}$ & ref. & ref. & ref. \\
\hline Black (“preta”) & $\begin{array}{l}1.42 * \\
(0.29)\end{array}$ & $\begin{array}{l}1.23 \\
(0.28)\end{array}$ & $\begin{array}{l}1.39 \\
(0.47)\end{array}$ \\
\hline Brown ("parda") & $\begin{array}{l}1.20 \\
(0.17)\end{array}$ & $\begin{array}{c}1.11 \\
(0.14)\end{array}$ & $\begin{array}{l}1.20 \\
(0.31)\end{array}$ \\
\hline Yellow/Asian (“amarela”) & $\begin{array}{c}1.04 \\
(0.33)\end{array}$ & $\begin{array}{l}1.03 \\
(0.32)\end{array}$ & $\begin{array}{c}0.30 \\
(0.29)\end{array}$ \\
\hline
\end{tabular}




\begin{tabular}{|c|c|c|c|}
\hline Indigenous ("indígena") & $\begin{array}{c}1.55 \\
(0.79)\end{array}$ & $\begin{array}{c}0.58 \\
(0.20)\end{array}$ & $\begin{array}{l}3.37 * \\
(2.16)\end{array}$ \\
\hline $\begin{array}{l}\text { Years of schooling at the time of interview } \\
0-3 \\
4-7\end{array}$ & $\begin{array}{c}0.94 \\
(0.17) \\
\text { ref. }\end{array}$ & $\begin{array}{c}0.82 \\
(0.20) \\
\text { ref. }\end{array}$ & $\begin{array}{c}1.37 \\
(0.37) \\
\text { ref. }\end{array}$ \\
\hline $\begin{array}{l}8-10 \\
11+\end{array}$ & $\begin{array}{l}1.07 \\
(0.17) \\
1.03 \\
(0.16)\end{array}$ & $\begin{array}{c}0.92 \\
(0.17) \\
0.83 \\
(0.15)\end{array}$ & $\begin{array}{c}1.10 \\
(0.30) \\
1.39 \\
(0.46)\end{array}$ \\
\hline $\begin{array}{l}\text { Model statistics } \\
\text { Log likelihood } \\
\text { Degrees of freedom } \\
\text { Likelihood Ratio Chi-Square } \\
\end{array}$ & $\begin{array}{c}-2,444.0 \\
24 \\
2,238.8 * * *\end{array}$ & $\begin{array}{c}-1,110.5 \\
24 \\
2,434.8^{* * *}\end{array}$ & $\begin{array}{c}-996.0 \\
24 \\
282.9 * * *\end{array}$ \\
\hline $\begin{array}{l}\text { Survey statistics } \\
\text { Number of strata } \\
\text { Number of primary sampling units (PSUs) } \\
\text { F-test }\end{array}$ & $\begin{array}{c}10 \\
994 \\
\mathrm{~F}(24 ; 961)= \\
48.5^{* * *} \\
17,376\end{array}$ & $\begin{array}{c}10 \\
718 \\
\mathrm{~F}(24 ; 685)= \\
14,044.6^{* * *}\end{array}$ & $\begin{array}{c}10 \\
789 \\
\mathrm{~F}(24 ; 756)= \\
8.9^{* * *} \\
12,342\end{array}$ \\
\hline
\end{tabular}

Note: Standard errors within parentheses. The log likelihood and the likelihood ratio chi-square were estimated without taking into account the complex survey design. All other statistics were estimated taking into account the complex survey design. ${ }^{* *} *$ Significant at $\mathrm{p}<0.01 ; * *$ Significant at $\mathrm{p}<0.05 ; *$ Significant at $\mathrm{p}<0.1$.

Source: 2006 Brazilian National Survey on Demography and Health of Children and Women (PNDS). 
Figure 1. Cumulative predicted hazards of sterilization from models in Table 3 by postpartum duration and place of delivery for women in the 25-29 age group, parity of two children, and living in the Brazilian Southeast, January 2001 to July 2007

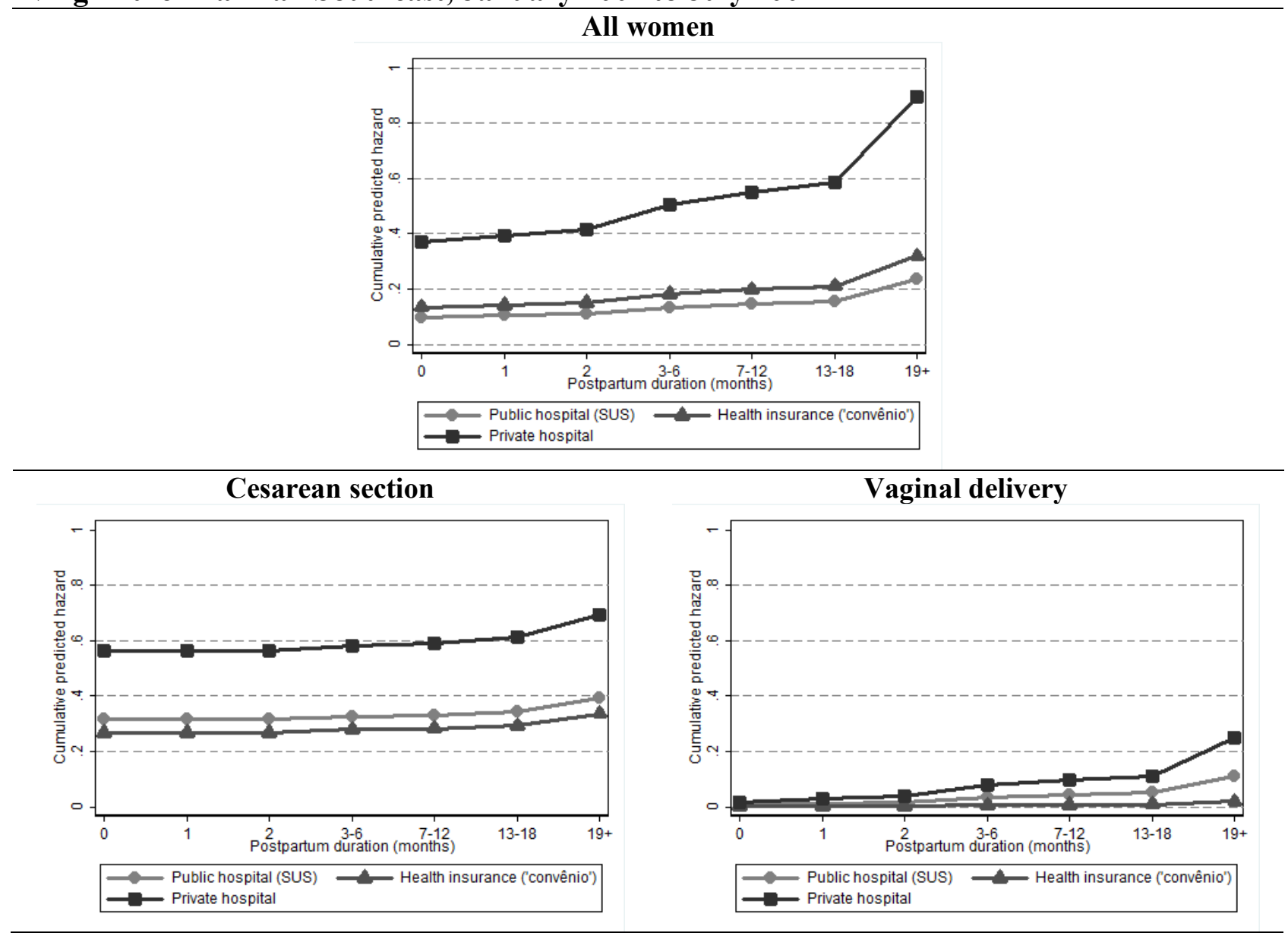

Note: The cumulative predicted hazards were estimated taking into account the complex survey design. The hazards represent the mean across the different color/race and years of schooling categories.

Source: 2006 Brazilian National Survey on Demography and Health of Children and Women (PNDS). 
Table 4. Exponentiated coefficients from a hazard model (hazard ratios) estimating the risk of sterilization (interaction models), Brazil, January 2001 to July 2007

\begin{tabular}{|c|c|c|}
\hline Variables & $\begin{array}{c}\text { All } \\
\text { women }\end{array}$ & $\begin{array}{l}\text { Cesarean } \\
\text { Section }\end{array}$ \\
\hline $\begin{array}{l}\text { Age at delivery * Parity at delivery } \\
\text { Age } 15-24,2 \text { children }\end{array}$ & ref. & ref. \\
\hline Age $25-29,2$ children & $\begin{array}{c}2.78 * * * \\
(0.65)\end{array}$ & $\begin{array}{l}2.96 * * * \\
(0.77)\end{array}$ \\
\hline Age $30-34,2$ children & $\begin{array}{c}4.19 * * * \\
(1.18)\end{array}$ & $\begin{array}{c}3.38 * * * \\
(0.97)\end{array}$ \\
\hline Age $35-49,2$ children & $\begin{array}{c}4.51 * * * \\
(1.26)\end{array}$ & $\begin{array}{c}3.79 * * * \\
(1.21)\end{array}$ \\
\hline Age $15-24,3$ children & $\begin{array}{c}1.07 \\
(0.39)\end{array}$ & $\begin{array}{c}1.06 \\
(0.44)\end{array}$ \\
\hline Age $25-29,3$ children & $\begin{array}{c}2.41 * * \\
(0.86)\end{array}$ & $\begin{array}{l}2.14 * * \\
(0.81)\end{array}$ \\
\hline Age $30-34,3$ children & $\begin{array}{c}3.72 * * * \\
(1.48)\end{array}$ & $\begin{array}{c}3.51 * * * \\
(1.64)\end{array}$ \\
\hline Age $35-49,3$ children & $\begin{array}{c}3.03 * * * \\
(1.29)\end{array}$ & $\begin{array}{c}2.83 * * \\
(1.33)\end{array}$ \\
\hline Age $15-24,4$ children or more & $\begin{array}{c}2.27 * * \\
(0.93)\end{array}$ & $\begin{array}{c}1.59 \\
(0.76)\end{array}$ \\
\hline Age $25-29,4$ children or more & $\begin{array}{c}3.31 * * * \\
(1.25)\end{array}$ & $\begin{array}{c}3.23 * * * \\
(1.31)\end{array}$ \\
\hline Age $30-34,4$ children or more & $\begin{array}{c}3.29 * * * \\
(1.28)\end{array}$ & $\begin{array}{c}3.30 * * \\
(1.60)\end{array}$ \\
\hline Age $35-49,4$ children or more & $\begin{array}{l}4.56^{* * *} \\
(1.53)\end{array}$ & $3.11 * *$ \\
\hline $\begin{array}{l}\text { Place of delivery * Postpartum duration } \\
\text { Public hospital (SUS), } 0 \text { months }\end{array}$ & ref. & ref. \\
\hline Public hospital (SUS), 1 month & $\begin{array}{c}0.10^{* * *} \\
(0.03)\end{array}$ & $\begin{array}{c}3.32 \mathrm{e}-18 * * * \\
(3.96 \mathrm{e}-19)\end{array}$ \\
\hline Public hospital (SUS), 2 months & $\begin{array}{c}0.10 * * * \\
(0.03)\end{array}$ & $\begin{array}{c}0.01 * * * \\
(0.00)\end{array}$ \\
\hline Public hospital (SUS), 3-6 months & $\begin{array}{c}0.10^{* * *} \\
(0.02)\end{array}$ & $\begin{array}{c}0.01 * * * \\
(0.01)\end{array}$ \\
\hline Public hospital (SUS), 7-12 months & $\begin{array}{c}0.04 * * * \\
(0.01)\end{array}$ & $\begin{array}{l}0.01 * * * \\
(0.00)\end{array}$ \\
\hline Public hospital (SUS), 13-18 months & $\begin{array}{c}0.03 * * * \\
(0.01)\end{array}$ & $\begin{array}{c}0.01 * * * \\
(0.01)\end{array}$ \\
\hline Public hospital (SUS), 19+ months & $\begin{array}{c}0.02 * * * \\
(0.01)\end{array}$ & $\begin{array}{c}0.01 * * * \\
(0.01)\end{array}$ \\
\hline Health insurance ("convênio"), 0 months & $\begin{array}{c}1.65 \\
(0.94)\end{array}$ & $\begin{array}{c}0.75 \\
(0.41)\end{array}$ \\
\hline Health insurance ("convênio"), 1 month & $\begin{array}{c}5.11 \mathrm{e}-18 * * * \\
(3.07 \mathrm{e}-18)\end{array}$ & $\begin{array}{c}2.03 \mathrm{e}-18 * * * \\
(1.19 \mathrm{e}-18)\end{array}$ \\
\hline Health insurance ("convênio"), 2 months & $\begin{array}{c}0.02 * * * \\
(0.03)\end{array}$ & $\begin{array}{c}2.12 \mathrm{e}-18 * * * \\
(1.21 \mathrm{e}-18)\end{array}$ \\
\hline Health insurance ("convênio"), 3-6 months & $\begin{array}{c}0.02 * * * \\
(0.02)\end{array}$ & $\begin{array}{c}0.01 * * * \\
(0.01)\end{array}$ \\
\hline Health insurance ("convênio"), 7-12 months & $\begin{array}{c}5.19 \mathrm{e}-18 * * * \\
(3.03 \mathrm{e}-18)\end{array}$ & $\begin{array}{c}2.06 \mathrm{e}-18 * * * \\
(1.19 \mathrm{e}-18)\end{array}$ \\
\hline Health insurance ("convênio"), 13-18 months & $\begin{array}{c}5.12 \mathrm{e}-18 * * * \\
(3.00 \mathrm{e}-18)\end{array}$ & $\begin{array}{c}2.03 \mathrm{e}-18 * * * \\
(1.18 \mathrm{e}-18)\end{array}$ \\
\hline Health insurance ("convênio"), $19+$ months & $\begin{array}{c}0.01 * * * \\
(0.00)\end{array}$ & $\begin{array}{c}0.01 * * * \\
(0.00)\end{array}$ \\
\hline Private hospital, 0 months & $\begin{array}{c}5.32 * * * \\
(1.52)\end{array}$ & $\begin{array}{c}1.96^{* * *} \\
(0.43)\end{array}$ \\
\hline Private hospital, 1 month & $\begin{array}{c}7.23 \mathrm{e}-18 * * * \\
(2.41 \mathrm{e}-18)\end{array}$ & $\begin{array}{c}2.78 \mathrm{e}-18 * * * \\
(7.20 \mathrm{e}-19)\end{array}$ \\
\hline
\end{tabular}


Private hospital, 2 months

Private hospital, 3-6 months

$7.24 \mathrm{e}-18 * * *$

(2.43e-18)

$7.24 \mathrm{e}-18 * * *$

$(2.45 \mathrm{e}-18)$

$0.01 * * *$

$(0.00)$

Private hospital, 7-12 months

Private hospital, 13-18 months

Private hospital, 19+ months

$(2.71 \mathrm{e}-18)$

$0.01 * * *$
$7.52 \mathrm{e}-18 * * *$

$(0.01)$

Place of delivery * Parity at delivery

Public hospital (SUS), 2 children

Public hospital (SUS), 3 children

Public hospital (SUS), 4 children or more

Health insurance ("convênio"), 2 children

Health insurance ("convênio"), 3 children

Health insurance ("convênio"), 4 children or more

Private hospital, 2 children

Private hospital, 3 children

Private hospital, 4 children or more

\section{Region of residence at the time of interview} North

Northeast

Southeast

South

Central-West

\section{Color/Race}

White ("branca")

Black ("preta")

Brown ("parda")

Yellow/Asian (“amarela")

Indigenous ("indígena")

ref.

0.97

$(0.35)$

$0.51 * *$

$(0.17)$

1.58

$(0.84)$

0.82

(0.48)

dropped

dropped

dropped

dropped

(0.22)

$1.35 *$

(0.21)

ref.

0.74

(0.13)

1.14

(0.18)

ref.

1.40 *

(0.28)

1.21

(0.16)

1.04

(0.34)

1.55

(0.76)

Years of schooling at the time of interview
$0-3$

$$
4-7
$$

$$
8-10
$$

$11+$

\section{Model statistics}

Log likelihood

Degrees of freedom

0.96

$(0.17)$

ref.

1.06

$(0.17)$

1.00

(0.16)

$-2,370.9$

46
$2.80 \mathrm{e}-18^{* * *}$

(7.32e-19)

$2.80 \mathrm{e}-18 * * *$

(7.38e-19)

$0.01 * * *$

(0.00)

$2.84 \mathrm{e}-18 * * *$

(7.97e-19)

$0.01 * * *$

$(0.00)$

ref.

0.73

$(0.27)$

$0.46^{* *}$

(0.18)

1.39

(0.75)

0.69

(0.42)

dropped

dropped

dropped

dropped

0.99

(0.19)

1.23

(0.21)

ref.

0.71 *

(0.13)

0.95

(0.16)

ref.

1.23

(0.29)

1.11

(0.15)

1.02

(0.32)

0.57

$(0.21)$

0.865

(0.205)

ref.

0.90

$(0.17)$

0.82

(0.15)

$-1,093.4$

46 


\begin{tabular}{l|c|c} 
Likelihood Ratio Chi-Square & $2,385.0^{* * *}$ & $2,469.0^{* * *}$ \\
\hline Survey statistics & & \\
Number of strata & 10 & 10 \\
Number of primary sampling units (PSUs) & 994 & 718 \\
F-test & $\mathrm{F}(46 ; 939)=$ & $\mathrm{F}(46 ; 663)=$ \\
\hline Number of observations & $5,464.5^{* * *}$ & $15,021.4^{* * *}$ \\
\hline
\end{tabular}

Note: Standard errors within parentheses. The log likelihood and the likelihood ratio chi-square were estimated without taking into account the complex survey design. All other statistics were estimated taking into account the complex survey design. ${ }^{* * *}$ Significant at $\mathrm{p}<0.01 ; * *$ Significant at $\mathrm{p}<0.05 ; *$ Significant at $\mathrm{p}<0.1$.

Source: 2006 Brazilian National Survey on Demography and Health of Children and Women (PNDS). 


\section{REFERENCES}

Amorim, F. A., Cavenaghi, S. M., \& Alves, J. E. D. (2008). Mudanças recentes no uso de métodos contraceptivos no Brasil e na Colômbia: com especial menção à esterilização masculina e feminina. In L. R. Wong (Ed.), Población y Salud Sexual y Reproductiva en América Latina (Vol. 4, pp. 101-130). Rio de Janeiro: Asociación Latinoamericana de Población (ALAP).

Barbosa, R. M., \& Knauth, D. R. (2003). Esterilização feminina, AIDS e cultura médica: os casos de São Paulo e Porto Alegre, Brasil. Cadernos de Saúde Pública, 19(Sup. 2), S365-S376.

Berquó, E. (1999). Ainda a questão da esterilização feminina no Brasil. In K. Giffin \& S. H. Costa (Eds.), Questões de Saúde Reprodutiva (pp. 113-126). Rio de Janeiro: Editora Fiocruz.

Berquó, E., \& Cavenaghi, S. (2003). Direitos reprodutivos de mulheres e homens face à nova legislação brasileira sobre esterilização voluntária. Cadernos de Saúde Pública, 19(Sup. 2), S441-S453.

Berquó, E., Garcia, S., \& Lago, T. (Eds.). (2008). PNDS 2006, Pequisa Nacional de Demografia e Saúde da Criança e da Mulher: Relatório. Brasília: Ministério da Saúde.

Bilac, E. D., \& Rocha, M. I. B. (Eds.). (1998). Saúde Reprodutiva na América Latina e no Caribe: Temas e Problemas. Campinas: Programa Latinoamericano de Actividades en Población (PROLAP); Associação Brasileira de Estudos de População (ABEP); Núcleo de Estudos de População (NEPO) da Universidade Estadual de Campinas (UNICAMP).

Blossfeld, H. P., Golsch, K., \& Rohwer, G. (2007). Techniques of Event History Modeling using Stata: New Approaches to Causal Analysis. Mahwah: Lawrence Erlbaum Associates, Inc., Publishers.

Blossfeld, H. P., \& Rohwer, G. (2002). Techniques of Event History Modeling: New Approaches to Causal Analysis. Mahwah: Lawrence Erlbaum Associates, Inc., Publishers.

Lei n. 9.263, de 12 de janeiro de 1996. Regula o parágrafo 7 do artigo 226 da Constituição Federal, que trata do planejamento familiar, estabelece penalidades e dá outras providências, (1996).

Caetano, A. J. (2014). Esterilização cirúrgica feminina no Brasil, 2000 a 2006: Aderência à lei de planejamento familiar e demanda frustrada. Revista Brasileira de Estudos de População, 31(2), 309-331.

Caetano, A. J., \& Potter, J. E. (2004). Politics and female sterilization in Northeast Brazil. Population and Development Review, 30(1), 79-108.

Carvalho, L. E. C., Osis, M. J. D., Cecatti, J. G., Bento, S. F., \& Manfrinati, M. B. (2007). Esterilização cirúrgica voluntária na Região Metropolitana de Campinas, São Paulo, Brasil, antes e após sua regulamentação. Cadernos de Saúde Pública, 23(12), 2906-2916.

Cavenaghi, S., \& Alves, J. E. D. (2009). Fertility and contraception in Latin America: historical trends, recent patterns. In S. Cavenaghi (Ed.), Demographic Transformations and Inequalities in Latin America: Historical Trends and Recent Patterns. Rio de Janeiro: Latin American Population Association (ALAP).

Costa, N. D. L., Paes, N. A., Ramos, P. C. F., \& Formiga, M. C. C. (2006). Desejo, intenção e comportamento na saúde reprodutiva: a prática da cesárea em cidade do Nordeste do Brasil. Revista Brasileira de Ginecologia e Obstetrícia, 28(7), 388-396.

Cunha, A. C. R., Wanderley, M. S., \& Garrafa, V. (2007). Fatores associados ao futuro reprodutivo de mulheres desejosas de gestação após ligadura tubária. Revista Brasileira de Ginecologia e Obstetricia, 29(5), 230-234.

Curtis, K. M., Mohllajee, A. P., \& Peterson, H. B. (2006). Regret following female sterilization at a young age: a systematic review. Contraception, 73, 205-210.

Fernandes, A. M. S., Arruda, M. S., Palhares, M. A. R., Benetti Júnior, N. D., \& Moreira, C. M. (2001). Seguimento de mulheres laqueadas arrependidas em serviço público de esterilidade conjugal. Revista Brasileira de Ginecologia e Obstetrícia, 23(2), 69-73.

Fonseca Sobrinho, D. (1993). Estado e População: uma História do Planejamento Familiar no Brasil. Rio de Janeiro: Editora Rosa dos Tempos; Fundo de População das Nações Unidas (FNUAP). 
Giffin, K., \& Costa, S. H. (1999). Questões da Saúde Reprodutiva. Rio de Janeiro: Editora Fiocruz.

Godecker, A. L., Thomson, E., \& Bumpass, L. L. (2001). Union status, marital history and female contraceptive sterilization in the United States. Family Planning Perspectives, 33(1), 25$41+49$.

Hopkins, K. (2009). Getting sterilized in Brazil: stories of sucess and failure. In P. Miranda-Ribeiro \& A. B. Simão (Eds.), Qualificando os Números: Estudos sobre Saúde Sexual e Reprodutiva no Brasil (pp. 167-183). Belo Horizonte: Associação Brasileira de Estudos Populacionais (ABEP); Fundo de População das Nações Unidas (UNFPA).

IBGE. (2012). Censo Demográfico 2010: Resultados Gerais da Amostra. Rio de Janeiro: Instituto Brasileiro de Geografia e Estatística (IBGE).

Janowitz, B., Higgins, J. E., Rodrigues, W., Arruda, J. M., Smith, J. B., \& Morris, L. (1985). Sterilization in the Northeast of Brazil. Social Science \& Medicine, 20(3), 215-221.

Lacerda, M. A., Miranda-Ribeiro, P., Caetano, A. J., \& Machado, C. J. (2005). Mensuração e perfis de demanda insatisfeita por contracepção nos municípios de Belo Horizonte e Recife, 2002. Revista Brasileira de Estudos de População, 22(1), 113-129.

Leon, J. G., \& Potter, J. E. (1989). Modelling the inverse association between breastfeeding and contraceptive use. Population Studies, 43(1), 69-93.

Leone, T., \& Hinde, A. (2005). Sterilization and union instability in Brazil. Journal of Biosocial Science, 37(4), 459-469.

Ludermir, A. B., Machado, K. M. M., Costa, A. M., Alves, S. V., \& Araújo, T. V. B. (2009). Tubal ligation regret and related risk factors: findings from a case-control study in Pernambuco state, Brazil. Cadernos de Saúde Pública, 25(6), 1361-1368.

Machado, K. M. M., Ludermir, A. B., \& Costa, A. M. (2005). Changes in famly structure and regret following tubal sterilization. Cadernos de Saúde Pública, 21(6), 1768-1777.

Minella, L. S. (2012). Esterilização feminina: temáticas e abordagens em periódicos científicos no Brasil (2000-2010). Paper presented at the 18th meeting of the Brazilian Association of Population Studies, Águas de Lindóia.

Miranda-Ribeiro, P., \& Simão, A. B. (2009). Qualificando os Números: Estudos sobre Saúde Sexual e Reprodutiva no Brasil. Belo Horizonte: Associação Brasileira de Estudos Populacionais (ABEP); Fundo de População das Nações Unidas (UNFPA).

Molina, A. (1999). Laqueadura tubária: situação nacional, internacional e efeitos colaterais. In K. Giffin \& S. H. Costa (Eds.), Questões da Saúde Reprodutiva (pp. 127-145). Rio de Janeiro: Editora Fiocruz.

Oliveira, M. C. (2003). Homens e contracepção: Análise estatística de dados qualitativos. Revista Brasileira de Estudos de População, 20(1), 63-77.

Oliveira, M. C., Bilac, E. D., \& Muszkat, M. (2009). Homens e anticoncepção: Um estudo sobre duas gerações masculinas das "camadas médias” paulistanas. In P. Miranda-Ribeiro \& A. B. Simão (Eds.), Qualificando os Números: Estudos sobre Saúde Sexual e Reprodutiva no Brasil (pp. 275-311). Belo Horizonte: Associação Brasileira de Estudos Populacionais (ABEP); Fundo de População das Nações Unidas (UNFPA).

Osis, M. J. D., Carvalho, L. E. C., Cecatti, J. G., Bento, S. F., \& Pádua, K. S. (2009). Atendimento à demanda pela esterilização cirúrgica na Região Metropolitana de Campinas, São Paulo, Brasil: percepção de gestores e profissionais dos serviços públicos de saúde. Cadernos de Saúde Pública, 25(3), 625-634.

Osis, M. J. D., Faúndes, A., Sousa, M. H., Duarte, G. A., \& Bailey, P. (2003). Fecundidade e história reprodutiva de mulheres laqueadas e não laqueadas de Campinas, São Paulo, Brasil. Cadernos de Saúde Pública, 19(5), 1399-1404.

Perpétuo, I. H. O. (1998). Contracepção e declínio da fecundidade na Região Nordeste. Revista Brasileira de Estudos de População, 15(1), 43-56.

Perpétuo, I. H. O., \& Wajnman, S. (2003). Socioeconomic correlates of female sterilization in Brazil. In M. E. Cosio-Zavala (Ed.), Poverty, Fertility and Family Planning (pp. 311-333). Paris: CICRED. 
Perpétuo, I. H. O., \& Wong, L. R. (2009). Desigualdade socioeconômica na utilização de métodos anticoncepcionais no Brasil: uma análise comparativa com base nas PNDS 1996 e 2006. In Brasil (Ed.), Pesquisa Nacional de Demografia e Saúde da Criança e da Mulher - PNDS 2006: Dimensões do Processo Reprodutivo e da Saúde da Criança (pp. 87-104). Brasília: Ministério da Saúde; Centro Brasileiro de Análise e Planejamento (CEBRAP).

Potter, J. E. (1999). The persistence of outmoded contraceptive regimes: the cases of Mexico and Brazil. Population and Development Review, 25(4), 703-739.

Potter, J. E., Perpétuo, I. H. O., Berquó, E., Hopkins, K., Leal, O. F., Formiga, M. C. C., \& Souza, M. R. (2003). Frustrated demand for postpartum female sterilization in Brazil. Contraception, 67, 385-390.

Schor, N., Ferreira, A. F., Machado, V. L., França, A. P., Pirotta, K. C. M., Alvarenga, A. T., \& Siqueira, A. A. F. (2000). Mulher e anticoncepção: conhecimento e uso de métodos anticoncepcionais. Cadernos de Saúde Pública, 16(2), 377-384.

Singer, J. D., \& Willett, J. B. (2003). Applied Longitudinal Data Analysis: Modeling Change and Event Occurrence. New York: Oxford University Press.

Steele, F. (2003). A discrete-time multilevel mixture model for event history data with long-term survivors, with an application to an analysis of contraceptive sterilization in Bangladesh. Lifetime Data Analysis, 9, 155-174.

Vieira, E. M. (2007). O arrependimento após a esterilização cirúrgica e o uso das tecnologias reprodutivas. Revista Brasileira de Ginecologia e Obstetrícia, 29(5), 225-229.

Vieira, E. M., Fábio, S. V., Gueleri, W., Picado, M. P., Yoshinaga, E., \& Souza, L. (2005). Características dos candidatos à esterilização cirúrgica e os fatores associados ao tipo de procedimento. Cadernos de Saúde Pública, 21(6), 1785-1791.

Vieira, E. M., \& Souza, L. (2009). Access to surgical sterilization through the National Health System, Ribeirão Preto, Southeastern Brazil. Revista de Saúde Pública, 43(3), 398-404.

White, K., \& Potter, J. E. (2014). Reconsidering racial/ethnic differences in sterilization in the Unites States. Contraception, 89, 550-556. 